$\begin{array}{llcccccrr}\text { Volume } & 12, \quad \text { Nomor } & 1, \quad \text { Mei } & \text { 2020, } & \text { pp } 23-46 & \text { Copyright } & \text { C } & 2017 \\ \text { Jurnal } & \text { Akuntansi, } & \text { Program } & \text { Studi } & \text { Akuntansi, } & \text { Fakultas } & \text { Ekonomi, } \\ \text { Universitas } & \text { Kristen } & \text { Maranatha. } & \text { ISSN } & 2085-8698 & \text { e-ISSN } & 2598-4977 .\end{array}$

http://journal.maranatha.edu

\title{
Menelusuri Keberhasilan dan Kendala Pemda di Provinsi Jawa Barat dalam Upaya Memperoleh Opini WTP dari BPK: Studi Kasus Pemerintah Daerah Kabupaten/Kota di Provinsi Jawa Barat
}

\author{
Puji Astuti Rahayu \\ Fakultas Ekonomi Program Studi Akuntansi-Univ.Katolik Parahyangan \\ (Jl.Ciumbuleuit No.94, Bandung) \\ pujirahayu@unpar.ac.id \\ Sylvia Fettry \\ Fakultas Ekonomi Program Studi Akuntansi-Univ.Katolik Parahyangan \\ (Jl.Ciumbuleuit No.94, Bandung) \\ sylvia.fettry@unpar.ac.id \\ Monica Paramita \\ Fakultas Ekonomi Program Studi Akuntansi-Univ.Katolik Parahyangan \\ (Jl.Ciumbuleuit No.94, Bandung) \\ monica.paramita@unpar.ac.id
}

\begin{abstract}
Financial management reforms to improve quality are continuously carried out. Regional financial management is carried out in an integrated system embodied in the Local Government Budget which is determined annually by regional regulations. The drafting of the Local Government Budget is guided by the Local Government Work in order to realize services to the community to achieve the goal of the state. It requires an inflow of funds to finance regional expenditure. Regional sources of revenue can be obtained from three sources: a) local own source revenue, b) fiscal balance transfers from the central government to regions, c) other local own source revenue. As a form of transparent and accountable regional financial management, it is necessary to prepare financial reports audited by the BPK. Basesd on the result of the audit, the local government experienced improvement and decreased Opinion on The Report On Local Government Finance from 2013 to 2016. Opinion that have been achieved are an illustration of the success in the presenting of the financial statement and the constraints faced by the Regional Government in West Java Province in obtain WTP Opinions from BPK. This research is descriptive, and data collection techniques is questionnaires, study of literature from Report of Audit Findings and interviews with related parties.
\end{abstract}

Keywords: Success, Constraints, Financial Management, and Audit Opinion 


\begin{abstract}
Abstrak
Reformasi pengelolaan keuangan untuk meningkatkan kualitas terus-menerus dilakukan. Pengelolaan keuangan daerah dilaksanakan dalam suatu sistem yang terintegrasi diwujudkan dalam Anggaran Pendapatan dan Belanja Daerah (APBD) yang setiap tahun ditetapkan dengan peraturan daerah. Penyusunan APBD berpedoman kepada Rencana Kerja Pemerintah Daerah (RKPD) dalam rangka mewujudkan pelayanan kepada masyarakat untuk tercapainya tujuan bernegara. Agar rencana keuangan pemerintah daerah dapat terwujud maka membutuhkan aliran dana masuk untuk membiayai belanja daerah. Sumber-sumber penerimaan daerah dapat diperoleh dari tiga sumber: a) pendapatan asli daerah b) dana perimbangan, dan c) lain-lain pendapatan daerah yang sah. Sebagai bentuk pertanggungjawaban pengelolaan keuangan daerah yang transparan dan akuntabel, maka perlu menyusun laporan keuangan yang diaudit oleh BPK. Berdasarkan hasil audit, pemerintah daerah yang mengalami perbaikan dan penurunan opini atas Laporan Keuangan Pemerintah Daerah dari tahun 2013 sampai dengan 2016. Opini yang telah dicapai merupakan gambaran keberhasilan dalam penyajian laporan keuangan dan kendala yang dihadapi oleh Pemda di Provinsi Jawa Barat dalam memperoleh opini WTP dari BPK. Penelitian ini adalah deskriptif, dan teknik pengumpulan data dilakukan dengan cara menyebarkan kuesioner dan wawancara kepada pihak terkait.
\end{abstract}

\title{
Kata Kunci: Keberhasilan, Kendala, Pengelolaan Keuangan, dan Opini Audit
}

\section{Pendahuluan}

Reformasi pada periode ini ditandai dengan adanya perubahan sistem pemerintahan yaitu dari sentralisasi ke desentralisasi. Sistem desentralisasi melahirkan otonomi daerah. (Halim dan Kusufi, 2014) Otonomi daerah diatur dengan Undang-Undang No 32 Tahun 2004 tentang Pemerintahan Daerah. Otonomi daerah merupakan hak, wewenang, serta kewajiban daerah otonom guna mengurus dan mengatur sendiri urusan pemerintahan serta kepentingan masyarakatnya sesuai dengan peraturan perundang-undangan yang berlaku.

Aturan pelaksanaan mengenai keuangan daerah telah diatur dalam Peraturan Pemerintah No.58 Tahun 2005 tentang Pengelolaan Keuangan Daerah, dan aturan teknis Peraturan Menteri Dalam Negeri No.21 Tahun 2011 tentang Pedoman Pengelolaan Keuangan Daerah. Pengelolaan keuangan daerah dilaksanakan dalam suatu sistem yang terintegrasi diwujudkan dalam Anggaran Pendapatan dan Belanja Daerah 24
(APBD) yang setiap tahun ditetapkan dengan peraturan daerah. Penyusunan APBD berpedoman kepada Rencana Kerja Pemerintah Daerah (RKPD) dalam rangka mewujudkan pelayanan kepada masyarakat untuk tercapainya tujuan bernegara. APBD sebagai alat pengelolaan keuangan Daerah yang memiliki fungsi otorisasi, perencanaan, pengawasan, alokasi, distribusi, dan stabilisasi.

Reformasi pengelolaan keuangan daerah tersebut memilki dampak perubahan, antara lain (Halim dan Kusufi, 2014):

a. Pemerintah daerah sebagai badan eksekutif, sedangkan DPRD sebagai badan legislatif. Setiap tahun Laporan Pertanggungjawaban Kepala Daerah disampaikan dan dibahas bersama DPRD.

b. Bentuk laporan pertanggungjawaban akhir tahun anggaran terdiri dari: nota perhitungan APBD, laporan perhitungan APBD, laporan aliran kas, neraca yang dilengkapi dengan penilaian kinerja 
yang berpedoman pada rencana strategis.

c. Pinjaman APBD dikelompokkan sebagai pos penerimaan.

d. Proses penyusunan APBD melibatkan unsur dalam masyarakat, selain pemda dan DPRD

e. Bentuk dan susunan APBD terdiri atas pendapatan, belanja, dan pembiayaan.

f. Standar pelayanan menjadi indikator kinerja pemda.

Sebagai bentuk pertanggungjawaban pengelolaan keuangan daerah yang transparan dan akuntabel, maka perlu menyusun laporan keuangan yang diaudit oleh BPK agar setiap pihak yang mengelola uang daerah akan menjalankan amanat tersebut dengan cara yang terbaik sehingga membawa manfaat sebesar-besarnya bagi rakyat. (BPK, 2016). Berdasarkan hasil audit, Laporan Keuangan beberapa pemerintah daerah memperoleh opini WTP (Wajar Tanpa Pengecualian) dan masih WDP (Wajar Dengan Pengecualian) dari tahun 2014 sampai dengan 2016.

Berdasarkan latar belakang tersebut, penelitian ini bertujuan untuk i) mendeskripsikan aspek yang menjadi pertimbangan BPK dalam memberikan opini terhadap Pemda di Provinsi Jawa Barat, ii) mendeskripsikan keberhasilan yang telah dicapai oleh Pemda dalam memperoleh opini WTP dari BPK, iii) mengidentifikasi kendala yang dihadapi oleh Pemda di Provinsi Jawa Barat sehingga belum memperoleh opini WTP dari BPK.

\section{Kerangka Teoritis}

\section{Pengelolaan Keuangan Daerah}

Pasal 1 ayat (6) PP No. 58 Tahun 2005 tentang Pengelolaan Keuangan Daerah menjabarkan pengelolaan keuangan daerah sebagai keseluruhan kegiatan yang meliputi perencanaan, pelaksanaan, penatausahaan, pelaporan, pertanggungjawaban, dan pengawasan keuangan daerah. Ruang lingkup pengelolaan keuangan daerah meliputi: a) hak daerah untuk memungut pajak daerah dan retribusi daerah serta melakukan pinjaman; b) kewajiban daerah untuk menyelenggarakan urusan pemerintahan daerah dan membayar tagihan pihak ketiga; c) penerimaan daerah; d) pengeluaran daerah; e) kekayaan daerah yang dikelola sendiri atau oleh pihak lain berupa uang, surat berharga, piutang, barang, serta hak-hak lain yang dapat dinilai dengan uang, termasuk kekayaan yang dipisahkan pada perusahaan daerah; dan f) kekayaan pihak lain yang dikuasai oleh pemerintah daerah dalam rangka penyelenggaraan tugas pemerintahan daerah dan/atau kepentingan umum.

\section{APBD}

Struktur APBD berdasarkan PP No. 58 Tahun 2005 terdiri dari:

a) Pendapatan daerah, meliputi semua penerimaan uang melalui Rekening Kas Umum Daerah, yang menambah ekuitas dana lancar, yang merupakan hak daerah dalam satu tahun anggaran yang tidak perlu dibayar kembali oleh Daerah.

b) Belanja daerah, meliputi semua pengeluaran dari Rekening Kas Umum Daerah yang mengurangi ekuitas dana lancar, yang merupakan kewajiban daerah dalam satu tahun anggaran yang tidak akan diperoleh pembayarannya kembali oleh Daerah.

c) Pembiayaan daerah, meliputi semua penerimaan yang perlu dibayar kembali dan/atau pengeluaran yang akan diterima kembali, baik pada tahun anggaran yang bersangkutan maupun pada tahun-tahun anggaran berikutnya. Pertanggungjawaban pelaksanaan APBD disusun oleh SKPD dan PPKD. SKPD bertanggungjawab untuk membuat Laporan Keuangan yang terdiri dari: 1) Laporan Realisasi Anggaran, 2) Neraca, dan 3) Catatan Atas Laporan Keuangan yang disampaikan kepada kepala daerah melalui Pejabat Pengelola Keuangan Daerah (PPKD) selambat-lambatnya 2 bulan 
setelah tahun anggaran berakhir. Berdasarkan Laporan Keuangan SKPD, PPKD menyusun Laporan Keuangan Pemerintah Daerah (LKPD) yang terdiri dari: 1) Laporan Realisasi Anggaran, 2) Neraca, dan 3) Laporan Arus Kas, dan 4) Catatan Atas Laporan Keuangan yang disusun dan disajikan sesuai Standar Akuntansi Pemerintahan. LKPD tersebut dilampiri dengan laporan ikhtisar realisasi kinerja (laporan operasional) dan laporan keuangan badan usaha milik daerah/perusahaan daerah. LKPD disampaikan kepada Kepala Daerah untuk memenuhi pertanggungjawaban pelaksanaan APBD.

Dalam PP No. 58 Tahun 2005, disebutkan pula bahwa LKPD disampaikan kepada BPK selambat-lambatnya 3 bulan setelah tahun anggaran berakhir. Pemeriksaan oleh BPK diselesaikan selambat-lambatnya 2 bulan setelah menerima laporan keuangan dari Pemerintah Daerah. Apabila setelah dilakukan audit oleh BPK didapatkan temuan atau koreksi, maka Kepala Daerah harus memberikan tanggapan dan melakukan penyesuaian terhadap laporan keuangan berdasarkan hasil pemeriksaan BPK.

\section{Pemeriksaan Keuangan}

Jenis pemeriksaan terdiri dari pemeriksaan keuangan, pemeriksaan kinerja, dan pemeriksaan untuk tujuan tertentu. Indra Bastian (2014: 17) menyatakan bahwa pemeriksaan keuangan meliputi pemeriksaan atas laporan keuangan dan hal yang berkaitan dengan keuangan. Tujuannya untuk memberikan keyakinan apakah laporan keuangan telah disajikan secara wajar dan sesuai dengan standar akuntansi pemerintahan.

Setelah selesai pemeriksaan dilakukan, pemeriksa akan menyusun laporan hasil pemeriksaan. Dalam penjelasan Pasal 16 UU No. 15 Tahun 2014, opini didefinisikan sebagai pernyataan profesional pemeriksa mengenai kewajaran informasi keuangan yang disajikan dalam laporan keuangan yang didasarkan pada:

a. Kesesuaian dengan standar akuntansi pemerintahan

b. Kecukupan pengungkapan (adequate disclosures)

c. Kepatuhan terhadap peraturan perundang-undangan

d. Efektivitas sistem pengendalian intern

Terdapat 4 jenis opini yang dapat diberikan oleh pemeriksa (BPK), yakni:

a. Opini wajar tanpa pengecualian (unqualified opinion)

b. Opini wajar dengan pengecualian (qualified opinion)

c. Opini tidak wajar (adversed opinion)

d. Pernyataan menolak memberikan opini (disclaimer of opinion).

\section{Penelitian Terdahulu}

Penelitian Budiartha (2007) menyatakan bahwa kesungguhan pemerintah daerah dalam mematuhi aturan dan perundangundangan yang berlaku dalam mengelola keuangan negara sangat sedikit. Penelitian Wulandari dan Bandi (2015) menghasilkan Implementasi e-government dan tindak lanjut hasil pemeriksaan BPK berpengaruh signifikan positif pada opini audit BPK. Sementara kapabilitas APIP tidak berpengaruh signifikan terhadap opini BPK. Adelia Pramita Sari, Dwi Martani, dan Dyah Setyaningrum (2015) menyatakan Temuan audit, tindak lanjut hasil pemeriksaan, dan kualitas SDM berpengaruh terhadap opini audit melalui pengungkapan laporan keuangan.

\section{Metode Penelitian}

Penelitian ini termasuk dalam penelitian kualitatif deskriptif

\section{Teknik Pengumpulan Data}

Jenis wawancara yang digunakan dalam penelitian ini yaitu wawancara semi terstruktur yang termasuk dalam kategori 
in-dept interview, tujuannya untuk menemukan permasalahan secara terbuka, dimana pihak yang diajak wawancara diminta pendapatnya. Wawancara dilakukan dengan auditor BPK. Selain itu, pengumpulan data juga menggunakan teknik dokumentasi yaitu menganalisis Laporan Hasil Pemeriksaan Laporan Keuangan Pemerintah Daerah tahun 2014 sampai dengan tahun 2016.

\section{Teknik Analisis Data}

Analisis penelitian kualitatif telah dimulai sejak merumuskan dan menjelaskan masalah, sebelum terjun ke lapangan dan berlangsung terus sampai penulisan hasil penelitian (Nasution dalam Sugiyono, 2008). Analisis mendalam akan dilakukan untuk menggali seluruh hal yang berhubungan dengan keberhasilan dan kendala pemda di Provinsi Jawa Barat dalam upaya memperoleh opini BPK.

\section{Hasil Penelitian dan Pembahasan}

\section{Pertimbangan BPK Dalam Pemberian Opini}

BPK berwenang untuk melakukan pemeriksaan berdasarkan Standar Pemeriksaan Keuangan Negara atas Laporan Keuangan Pemerintah Daerah (LKPD), yang terdiri dari: Neraca, Laporan Realisasi Anggaran, Laporan Perubahan Saldo Anggaran Lebih, Laporan Operasional, Laporan Arus Kas, Laporan Ekuitas dan Catatan atas Laporan Keuangan. Beberapa aspek yang menjadi pertimbangan BPK dalam memberikan opini, diantaranya (1) Pengendalian intern yang relevan dengan penyusunan dan penyajian laporan keuangan, (2) Ketepatan kebijakan akuntansi yang digunakan, (3) Kewajaran estimasi akuntansi, (4) Evaluasi penyajian laporan keuangan secara keseluruhan sesuai dengan Standar Akuntansi Pemerintahan, (5) Kepatuhan terhadap ketentuan peraturan perundangundangan, dan (6) Tindak lanjut rekomendasi BPK, dan (7) Kecukupan pengungkapan.

Berdasarkan hasil LHP TA 2014, 2015, 2016 terdapat 5 kota yang telah berhasil mendapatkan opini WTP (Wajar Tanpa Pengecualian) antara lain Kabupaten Bandung, Kota Cirebon, Kota Tasikmalaya, Kota Bogor, dan Kabupaten Pangandaran. Sedangkan Kabupaten Subang, Kota Bandung, dan Kabupaten Bandung Barat masih mendapatkan opini WDP (Wajar Dengan Pengecualian), berikut rekapitulasi opini BPK:

Tabel 1

Rekapitulasi opini BPK

\begin{tabular}{|l|c|c|c|}
\hline \multirow{2}{*}{ Kabupaten/Kota } & \multicolumn{3}{|c|}{ Opini BPK atas LKPD } \\
\cline { 2 - 4 } & TA & TA & TA \\
& 2014 & 2015 & 2016 \\
\hline Kab.Bandung & WDP & WDP & WTP \\
\hline Kota Cirebon & WDP & WDP & WTP \\
\hline Kota Tasikmalaya & WDP & WDP & WTP \\
\hline Kota Bogor & WDP & WDP & WTP \\
\hline $\begin{array}{l}\text { Kab. } \\
\text { Pangandaran }\end{array}$ & WDP & WDP & WTP \\
\hline KabupatenSubang & TMP & TMP & WDP \\
\hline Kota Bandung & WDP & WDP & WDP \\
\hline Kabupaten & WDP & WDP & WDP \\
\hline Bandung Barat & WD & & \\
\hline
\end{tabular}

Sumber: BPK 2017

\section{Keberhasilan Pemerintah Daerah Dalam Memperoleh Opini WTP}

Pada tahun anggaran 2016 beberapa Pemerintah Daerah yang akhirnya telah berhasil memperoleh opini WTP dari BPK, antara lain: Kabupaten Bandung, Kota Cirebon, Kota Tasikmalaya, Kota Bogor, dan Kabupaten Pangandaran. Opini WTP merupakan hasil dari pemeriksaan laporan keuangan, pemeriksaan atas pengendalian intern, dan pemeriksaan atas kepatuhan terhadap peraturan perundang-undangan.

\section{a. Pemeriksaan Laporan Keuangan Pemerintah Daerah}

Berikut rekapitulasi temuan BPK atas LKPD pada tahun anggaran (TA) 2014, 2015: 
Tabel 2

Rekapitulasi Temuan BPK

\begin{tabular}{|c|c|c|}
\hline $\begin{array}{l}\text { Kabupaten/ } \\
\text { Kota }\end{array}$ & TA 2014 & TA 2015 \\
\hline Kab.Bandung & Aset tetap & Aset tetap \\
\hline Kota Cirebon & Aset tetap & Aset tetap \\
\hline $\begin{array}{l}\text { Kota } \\
\text { Tasikmalaya }\end{array}$ & $\begin{array}{l}\text { - Dana } \\
\text { bergulir } \\
\text { - Aset tetap }\end{array}$ & Aset tetap \\
\hline Kota Bogor & Aset tetap & $\begin{array}{l}\text { - Piutang } \\
\text { retribusi } \\
\text { daerah } \\
\text { BPPT } \\
\text { - Piutang } \\
\text { lainnya } \\
\text { dan } \\
\text { penyisiha } \\
\text { nnya } \\
\text { - Aset } \\
\text { tetap }\end{array}$ \\
\hline $\begin{array}{l}\text { Kab. } \\
\text { Pangandaran }\end{array}$ & $\begin{array}{l}\text { - Persediaan } \\
\text { - Aset tetap }\end{array}$ & Aset tetap \\
\hline
\end{tabular}

Sumber: LHP BPK Perwakilan Provinsi Jabar 2017

Berdasarkan tabel rekapitulasi temuan BPK atas LKPD TA 2014, 2015, dan 2016 Kabupaten Bandung, Kota Cirebon, Kota Tasikmalaya, Kota Bogor, dan Kabupaten Pangandaran telah berhasil mengatasi masalah pada laporan keuangan TA 2014 dan 2015 sehingga pada TA 2016 tidak ada lagi temuan dari BPK, sehingga opini Kabupaten/Kota tersebut memperoleh opini WTP. Berikut penelusuran keberhasilan tiap Kabupaten/Kota dalam memperoleh opini WTP dari BPK:

1) Kabupaten Bandung
Tabel 3

Upaya Perbaikan Pemda Kabupaten Bandung

\begin{tabular}{|l|l|}
\hline No. & $\begin{array}{l}\text { Upaya perbaikan yang telah } \\
\text { dilakukan pada TA 2015 dan TA } \\
\text { 2016: }\end{array}$ \\
\hline 1 & $\begin{array}{l}\text { Menyajikan aset tetap kendaraan } \\
\text { yang belum } \\
\text { keberadaannya }\end{array}$ \\
\hline 2 & $\begin{array}{l}\text { Memperbaiki kesalahan klasifikasi } \\
\text { aset tetap jalan,irigasi, dan jaringan }\end{array}$ \\
\hline 3 & $\begin{array}{l}\text { Menyajikan nilai dan jumlah aset } \\
\text { tetap jalan, irigasi, dan jaringan }\end{array}$ \\
\hline 4 & Menyajikan aset tetap tanah \\
\hline 5 & $\begin{array}{l}\text { Menelusuri dan menyajikan aset } \\
\text { tetap dengan nilai Rp.0 dengan nilai } \\
\text { wajar }\end{array}$ \\
\hline
\end{tabular}

Sumber: LHP BPK Perwakilan Provinsi Jabar 2017

Pada TA 2016 Pemda Kabupaten Bandung telah menyelesaikan permasalahan yang ditemukan pada laporan keuangan TA 2015, dan menyajikan laporan keuangan TA 2016 secara wajar sesuai dengan Standar Akuntansi Pemerintah, sehingga berhasil memperoleh opini WTP dari BPK.

2) Kota Cirebon 
Tabel 4

Upaya Perbaikan Pemda Kota

Cirebon

\begin{tabular}{|l|l|}
\hline No. & $\begin{array}{l}\text { Upaya perbaikan yang telah } \\
\text { dilakukan pada TA 2015 dan TA } \\
\text { 2016: }\end{array}$ \\
\hline 1 & $\begin{array}{l}\text { Melakukan rekonsiliasi data tanah } \\
\text { dan ditindaklanjuti dengan koreksi } \\
\text { pencatatan tambah maupun kurang } \\
\text { pada masing-masing neraca }\end{array}$ \\
\hline 2 & $\begin{array}{l}\text { Inventarisasi barang milik daerah di } \\
\text { lingkungan Pemerintah Kota Cirebon } \\
\text { pada bulan September s.d Desember } \\
\text { 2016 yang ditindaklanjuti dengan } \\
\text { penghapusan, koreksi tambah, } \\
\text { koreksi kurang maupun reklasifikasi } \\
\text { pada aset tetap }\end{array}$ \\
\hline 3 & $\begin{array}{l}\text { Melaksanakan verifikasi dan } \\
\text { pemuktahiran data tanah di bawah } \\
\text { jalan, trotoar, drainase, yang } \\
\text { ditindaklanjuti dengan pencatatan } \\
\text { tambah maupun kurang sesuai } \\
\text { dengan kondisi di lapangan }\end{array}$ \\
\hline 4 & $\begin{array}{l}\text { Melakukan koreksi terkait tanah } \\
\text { yang bukan lagi menjadi hak Pemkot } \\
\text { Cirebon. }\end{array}$ \\
\hline
\end{tabular}

Sumber: LHP BPK Perwakilan Provinsi Jabar 2017

Koreksi yang dilakukan menyebabkan penyajian laporan keuangan menjadi wajar, sehingga pada TA 2016 Pemda Kota Cirebon berhasil memperoleh opini WTP.

3) Kota Tasikmalaya
Tabel 5

Upaya Perbaikan Pemda Kota Tasikmalaya

\begin{tabular}{|l|l|}
\hline No. & $\begin{array}{l}\text { Upaya perbaikan yang telah } \\
\text { dilakukan pada TA 2015 dan TA } \\
\text { 2016: }\end{array}$ \\
\hline 1 & $\begin{array}{l}\text { Melakukan kegiatan inventarisasi, } \\
\text { penilaian, pemuktahiran KIR dan } \\
\text { KIB secara tuntas dan menyeluruh, } \\
\text { sehingga dapat menyajikan seluruh } \\
\text { rincian dan nilai aset tetap secara } \\
\text { memadai }\end{array}$ \\
\hline 2 & $\begin{array}{l}\text { Menginventarisasi seluruh penerima } \\
\text { dana bergulir yang belum } \\
\text { diverifikasi sehingga dapat } \\
\text { dikelompokkan berdasarkan jangka } \\
\text { waktu dan tingkat ketertagihannya }\end{array}$ \\
\hline 3 & $\begin{array}{l}\text { Melakukan inventarisasi fisik dan } \\
\text { penelusuran dokumen pendukung } \\
\text { seperti Dokumen Pelaksanaan } \\
\text { Anggaran, Surat Perjanjian } \\
\text { Kerjasama, Rencana Anggaran dan } \\
\text { Biaya serta melakukan koreksi yang } \\
\text { diperlukan }\end{array}$ \\
\hline
\end{tabular}

Sumber: LHP BPK Perwakilan Provinsi Jabar 2017

4) Kota Bogor

Tabel 6

Upaya Perbaikan Pemda Kota Bogor

No. Upaya perbaikan yang telah dilakukan pada TA 2015 dan TA 2016:

$1 \quad$ Melakukan inventarisasi atas aset tetap tanah bekas tanah milik desa,

2 Melakukan inventarisasi atas aset tetap tanah bekas tanah milik desa,

$3 \quad$ Melakukan penilaian atas aset tetap yang bernilai $\mathrm{Rp} 0,00$ berdasarkan nilai wajar pada tahun perolehan

Melakukan koreksi dan melakukan penyisihan piutang pokok retribusi dan piutang lainnya sesuai dengan kebijakan akuntansi,

Sumber: LHP BPK Perwakilan Provinsi Jabar 2017 
Oleh karena itu, Pemda Kota Bogor telah berhasil memperoleh opini WTP pada LKPD TA 2016.

5) Kabupaten Pangandaran

Tabel 7

Upaya Perbaikan Pemda

Kabupaten Pangandaran

\begin{tabular}{|l|l|}
\hline No. & $\begin{array}{l}\text { Upaya perbaikan yang telah } \\
\text { dilakukan pada TA 2015, TA 2016, } \\
\text { dan TA 2017: }\end{array}$ \\
\hline 1 & $\begin{array}{l}\text { Menyajikan nilai persediaan } \\
\text { berdasarkan hasil stockopname dan } \\
\text { sesuai dengan standar akuntansi } \\
\text { pemerintah }\end{array}$ \\
\hline 2 & $\begin{array}{l}\text { Penelusuran aset tetap dan } \\
\text { melakukan koordinasi dengan } \\
\text { Pemda Ciamis }\end{array}$ \\
\hline 3 & $\begin{array}{l}\text { Menyajikan aset tetap berdasarkan } \\
\text { nilai perolehan }\end{array}$ \\
\hline 4 & $\begin{array}{l}\text { Melakukan koreksi yang diperlukan } \\
\text { sehingga penyajian laporan } \\
\text { keuangan menjadi wajar }\end{array}$ \\
\hline
\end{tabular}

Sumber: LHP BPK Perwakilan Provinsi Jabar 2017

b. Pemeriksaan atas pengendalian intern

Pemeriksaan atas sistem pengendalian intern dilakukan oleh BPK untuk menentukan prosedur pemeriksaan dalam rangka memberikan opini atas kewajaran laporan keuangan. Kelemahan dalam sistem pengendalian intern dapat dikelompokkan menjadi tiga jenis, yaitu kelemahan sistem pengendalian akuntansi dan pelaporan, kelemahan sistem pengendalian pelaksanaan anggaran pendapatan dan belanja, dan kelemahan struktur pengendalian intern. Berikut rekapitulasi pemeriksaan sistem pengendalian intern pada Kabupaten Bandung, Kota Cirebon, Kota Tasikmalaya, Kota Bogor, dan Kabupaten Pangandaran pada TA 2014, 2015, dan 2016:
Tabel 8

Hasil Pemeriksaan atas Sistem Pengendalian Intern Pemda Kabupaten Bandung TA 2014, TA 2015, dan TA 2016

\begin{tabular}{|l|c|c|c|}
\hline \multicolumn{1}{|c|}{ Tahun } & 2014 & 2015 & 2016 \\
\hline $\begin{array}{l}\text { Kelemahan } \\
\text { struktur } \\
\text { pengendalian } \\
\text { intern }\end{array}$ & $\sqrt{ }$ & $\sqrt{ }$ & $\sqrt{ }$ \\
\hline $\begin{array}{l}\text { Kelemahan } \\
\text { sistem } \\
\text { pengendalian } \\
\text { pelaksanaan } \\
\text { anggaran } \\
\text { pendapatan dan } \\
\text { belanja }\end{array}$ & $\sqrt{ }$ & - & - \\
\hline $\begin{array}{l}\text { Kelemahan } \\
\text { sistem } \\
\text { pengendalian } \\
\text { akuntansi dan } \\
\text { pelaporan }\end{array}$ & $\sqrt{ }$ & $\sqrt{ }$ & $\sqrt{ }$ \\
\hline
\end{tabular}

Sumber: LHP BPK Perwakilan Provinsi Jabar 2017

Kelemahan struktur pengendalian internal yang terjadi pada tahun 2014 sebesar $45 \%$ disebabkan oleh SOP yang belum disusun dan terdapat SOP yang tidak ditaati. Pada tahun 2015 ditemukan adanya SOP yang tidak ditaati sebesar 25\%, dan tahun 2016 SOP belum disusun sebesar $25 \%$. Kelemahan pada sistem pengendalian pelaksanaan anggaran pendapatan dan belanja pada tahun 2014 terjadi sebesar $26 \%$ disebabkan oleh penyimpangan terhadap peraturan dan adanya pelaksanaan kebijakan yang menyebabkan hilangnya potensi penerimaan. Kelemahan ini sudah dapat diatasi pada tahun 2015 dan 2016. Kelemahan sistem pengendalian akuntansi dan pelaporan yang terjadi pada tahun 2014 disebabkan oleh pencatatan belum dilakukan atau tidak akurat sebesar $18 \%$, tahun 2015 sebesar 75\%, tahun 2016 sebesar $75 \%$. 
Tabel 9

Hasil Pemeriksaan atas Sistem Pengendalian Intern Pemda Kota Cirebon TA 2014, TA 2015, dan TA 2016

\begin{tabular}{|l|c|c|c|}
\hline \multicolumn{1}{|c|}{ Tahun } & 2014 & 2015 & 2016 \\
\hline $\begin{array}{l}\text { Kelemahan } \\
\text { struktur } \\
\text { pengendalian } \\
\text { intern }\end{array}$ & $\sqrt{ }$ & $\sqrt{ }$ & $\sqrt{ }$ \\
\hline $\begin{array}{l}\text { Kelemahan } \\
\text { sistem } \\
\text { pengendalian } \\
\text { pelaksanaan } \\
\text { anggaran } \\
\text { pendapatan dan } \\
\text { belanja }\end{array}$ & - & - & $\sqrt{ }$ \\
\hline $\begin{array}{l}\text { Kelemahan } \\
\text { sistem } \\
\text { pengendalian } \\
\text { akuntansi dan } \\
\text { pelaporan }\end{array}$ & $\sqrt{ }$ & $\sqrt{ }$ & - \\
\hline
\end{tabular}

Sumber: LHP BPK Perwakilan Provinsi Jabar 2017

Kelemahan struktur pengendalian internal pada tahun 2014 terjadi karena SOP tidak ditaati dan utang kepada Bank belum terselesaikan sebesar $40 \%$, pada tahun 2015 sebesar 33\% karena SOP belum disusun dan adanya SOP yang tidak ditaati, pada tahun 2016 sebesar 33\% disebabkan karena SOP tidak ditaati.Kelemahan pada sistem pengendalian pelaksanaan anggaran pendapatan dan belanja tidak terjadi pada tahun 2014 dan 2015, namun pada tahun 2016 terjadi sebesar $67 \%$ disebabkan oleh perencanaan kegiatan tidak memadai dan pelaksanaan kebijakan menyebabkan hilangnya potensi penerimaan. Kelemahan sistem pengendalian akuntansi dan pelaporan pada tahun 2014 sebesar 60\% disebabkan oleh proses penyusunan laporan tidak sesuai ketentuan, dan tahun 2015 sebesar $67 \%$ karena pencatatan belum dilakukan atau tidak akurat, dan proses penyusunan laporan tidak sesuai ketentuan.
Tabel 10

Hasil Pemeriksaan atas Sistem Pengendalian Intern Pemda Kota Tasikmalaya TA 2014, TA 2015, dan TA 2016

\begin{tabular}{|l|c|c|c|}
\hline \multicolumn{1}{|c|}{ Tahun } & 2014 & 2015 & 2016 \\
\hline $\begin{array}{l}\text { Kelemahan } \\
\text { struktur } \\
\text { pengendalian } \\
\text { intern }\end{array}$ & $\sqrt{ }$ & $\sqrt{ }$ & - \\
\hline $\begin{array}{l}\text { Kelemahan } \\
\text { sistem } \\
\text { pengendalian } \\
\text { pelaksanaan } \\
\text { anggaran } \\
\text { pendapatan dan } \\
\text { belanja }\end{array}$ & $\sqrt{ }$ & $\sqrt{ }$ & - \\
\hline $\begin{array}{l}\text { Kelemahan } \\
\text { sistem } \\
\text { pengendalian } \\
\text { akuntansi dan } \\
\text { pelaporan }\end{array}$ & $\sqrt{ }$ & $\sqrt{ }$ & $\sqrt{ }$ \\
\hline
\end{tabular}

Sumber: LHP BPK Perwakilan Provinsi Jabar 2017

Kelemahan struktur pengendalian internal yang terjadi pada tahun 2014 disebabkan oleh SOP yang tidak ditaati sebesar $14 \%$ begitu pula dengan tahun 2015, namun pada tahun 2016 Pemda Tasikmalaya sudah berhasil mengatasinya. Kelemahan sistem pengendalian pelaksanaan anggaran pendapatan dan belanja pada tahun 2014 terjadi disebabkan oleh penyimpangan terhadap peraturan, dan adanya pelaksanaan kebijakan yang menyebabkan hilangnya potensi penerimaan sebesar $29 \%$, begitu juga dengan tahun 2015 sebesar 29\%. Kelemahan sistem pengendalian akuntansi dan pelaporan terjadi pada tahun 2014 karena pencatatan belum dilakukan, tidak akurat, dan proses penyusunan laporan tidak sesuai ketentuan sebesar 57\%, begitu pula dengan tahun 2015, sedangkan tahun 2016 terjadi sebesar $100 \%$. 
Tabel 11

Hasil Pemeriksaan atas Sistem

Pengendalian Intern Pemda Kota Bogor

TA 2014, TA 2015, dan TA 2016

\begin{tabular}{|l|c|c|c|}
\hline \multicolumn{1}{|c|}{ Tahun } & 2014 & 2015 & 2016 \\
\hline $\begin{array}{l}\text { Kelemahan } \\
\text { struktur } \\
\text { pengendalian } \\
\text { intern }\end{array}$ & $\sqrt{ }$ & $\sqrt{ }$ & $\sqrt{ }$ \\
\hline $\begin{array}{l}\text { Kelemahan } \\
\text { sistem } \\
\text { pengendalian } \\
\text { pelaksanaan } \\
\text { anggaran } \\
\text { pendapatan dan } \\
\text { belanja }\end{array}$ & $\sqrt{ }$ & - & $\sqrt{ }$ \\
\hline $\begin{array}{l}\text { Kelemahan } \\
\text { sistem } \\
\text { pengendalian } \\
\text { akuntansi dan } \\
\text { pelaporan }\end{array}$ & $\sqrt{ }$ & $\sqrt{ }$ & $\sqrt{ }$ \\
\hline
\end{tabular}

Sumber: LHP BPK Perwakilan Provinsi Jabar 2017

Kelemahan struktur pengendalian internal pada tahun 2014 terjadi SOP belum disusun, dan terdapat SOP yang tidak ditaati sebesar 62\%, pada tahun 2015 sebesar $14 \%$ karena SOP tidak ditaati, pada tahun 2016 sebesar 25\% disebabkan karena SOP tidak ditaati. Kelemahan sistem pengendalian pelaksanaan anggaran pendapatan dan belanja pada tahun 2014 sebesar $8 \%$ terjadi karena adanya perencanaan yang tidak memadai, tahun 2015 ditemukan adanya kelemahan, sedangkan pada tahun 2016 ditemukan kelemahan sebesar $25 \%$ terjadi karena adanya pelaksanaan kebijakan menyebabkan hilangnya potensi penerimaan. Kelemahan sistem pengendalian akuntansi dan pelaporan TA 2014 sebesar $31 \%$ karena adanya pencatatan belum dilakukan, tidak akurat, dan proses penyusunan laporan tidak sesuai ketentuan, TA 2015 sebesar 86\% dengan kasus yang sama, sedangkan TA 2016 sebesar $50 \%$ terjadi karena adanya pencatatan yang belum dilakukan dan tidak akurat.

Tabel 12

Hasil Pemeriksaan atas Sistem

Pengendalian Intern Pemda Kabupaten

Pangandaran TA 2014, TA 2015, dan TA

2016

\begin{tabular}{|l|c|l|l|}
\hline \multicolumn{1}{|c|}{ Tahun } & 2014 & 2015 & 2016 \\
\hline $\begin{array}{l}\text { Kelemahan } \\
\text { struktur } \\
\text { pengendalian } \\
\text { intern }\end{array}$ & - & $\sqrt{ }$ & $\sqrt{ }$ \\
\hline $\begin{array}{l}\text { Kelemahan } \\
\text { sistem } \\
\text { pengendalian } \\
\text { pelaksanaan } \\
\text { anggaran } \\
\text { pendapatan dan } \\
\text { belanja }\end{array}$ & $\sqrt{ }$ & $\sqrt{ }$ & $\sqrt{ }$ \\
\hline $\begin{array}{l}\text { Kelemahan } \\
\text { sistem } \\
\text { pengendalian } \\
\text { akuntansi dan } \\
\text { pelaporan }\end{array}$ & $\sqrt{ }$ & $\sqrt{ }$ & $\sqrt{ }$ \\
\hline
\end{tabular}

Sumber: LHP BPK Perwakilan Provinsi Jabar 2017

Pada TA 2014 tidak ditemukan adanya kelemahan struktur pengendalian internal, namun terdapat kelemahan sistem pengendalian pelaksanaan anggaran pendapatan dan belanja sebesar 25\% disebabkan oleh adanya pelaksanaan kebijakan yang menyebabkan hilangnya potensi penerimaan, sedangkan kelemahan pada sistem pengendalian akuntansi dan pelaporan sebesar $75 \%$ disebabkan oleh adanya pencatatan yang belum dilakukan atau tidak akurat, proses penyusunan laporan tidak sesuai ketentuan.

Pada TA 2015 terdapat kelemahan kelemahan struktur pengendalian internal sebesar 25\% disebabkan oleh SOP belum disusun, kelemahan pada sistem pengendalian akuntansi dan pelaporan sebesar $25 \%$ disebabkan oleh pencatatan belum dilakukan atau tidak akurat, kelemahan sistem pengendalian pelaksanaan anggaran pendapatan dan 
belanja sebesar 50\% disebabkan oleh penyimpangan terhadap peraturan tentang pendapatan dan belanja, dan adanya pelaksanaan kebijakan yang menyebabkan hilangnya potensi penerimaan. Pada TA 2016 masih terdapat kelemahan struktur pengendalian internal sebesar 33\% disebabkan oleh SOP tidak ditaati, kelemahan sistem pengendalian pelaksanaan anggaran pendapatan dan belanja sebesar $17 \%$ dikarenakan masih adanya pelaksanaan kebijakan yang menyebabkan hilangnya potensi penerimaan. Kelemahan pada sistem pengendalian akuntansi dan pelaporan sebesar 50\% karena pencatatan belum dilakukan dan proses penyusunan laporan tidak sesuai ketentuan.

Terhadap permasalahan sistem pengendalian intern tersebut, BPK merekomendasikan kepala daerah untuk memerintahkan pejabat atau pegawai yang bertanggungjawab untuk:

- Memberikan sanksi kepada pejabat atau pegawai yang lalai dan tidak cermat dalam menaati ketentuan yang berlaku,

- Menyusun kebijakan atau standard operating procedure sebagai pedoman melaksanakan tugas dan tanggungjawab,

- Meningkatkan pengawasan dan pengendalian atas pengelolaan keuangan termasuk keuangan yang dananya berasal dari pemerintah pusat,

- Meningkatkan koordinasi antar satuan kerja, dalam rangka menginventarisasi aset dan melengkapi catatan pendukungnya serta merekonsiliasi catatan pendapatan antara SKPD yang mengelola pendapatan dengan Bagian Akuntansi.

\section{c. Pemeriksaan atas kepatuhan terhadap peraturan perundang- undangan}

BPK melakukan pengujian terhadap peraturan perundang-undangan dan kecurangan yang berpengaruh material terhadap laporan keuangan. Hal ini sebagai bahan pertimbangan auditor BPK dalam memberikan opini atas laporan keuangan pemerintah daerah. Permasalahan ketidakpatuhan terhadap peraturan perundangundangan meliputi permasalahan ketidakpatuhan yang berdampak finansial terdiri dari permasalahan yang menyebabkan kerugian daerah, potensi kerugian daerah, dan kekurangan penerimaan. Selain itu, terdapat permasalahan ketidakpatuhan yang tidak berdampak finansial berupa penyimpangan administrasi.

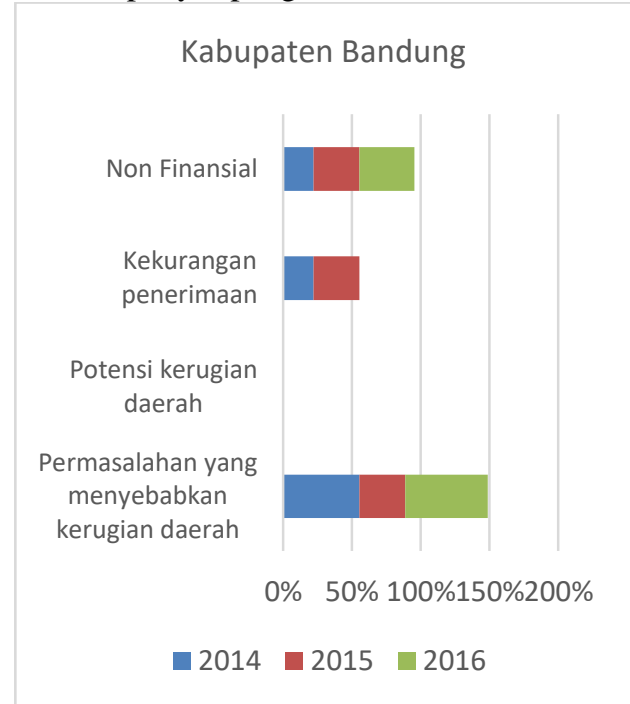

Sumber: Data diolah. 2017

Gambar 1

Rekapitulasi Pemeriksaan atas

Ketidakpatuhan Terhadap Peraturan

Perundang-Undangan Pada Pemda

Kabupaten Bandung TA 2014, TA 2015

dan TA 2016 
Berdasarkan hasil pemeriksaan atas ketidakpatuhan terhadap peraturan perundang-undangan pada Kabupaten Bandung TA 2014 ditemukan ketidakpatuhan sebagai berikut: (i) permasalahan yang menyebabkan kerugian daerah sebesar 56\% yaitu belanja tidak sesuai atau melebihi ketentuan, kelebihan pembayaran selain kekurangan volume pekerjaan dan atau barang, biaya perjalanan dinas ganda dan atau melebihi standar yang ditetapkan, (ii) kekurangan penerimaan sebesar $22 \%$ yaitu penerimaan daerah termasuk denda keterlambatan pekerjaan belum dipungut atau diterima, (iii) non finansial sebesar $22 \%$ yaitu bukti pertanggungjawaban tidak lengkap atau valid dan penyetoran penerimaan negara atau daerah terlambat. Tahun 2015 ditemukan ketidakpatuhan, seperti: (i) permasalahan yang menyebabkan kerugian daerah sebesar $34 \%$ yaitu kelebihan pembayaran selain kekurangan volume pekerjaan dan atau barang (ii) kekurangan penerimaan sebesar $33 \%$ yaitu penerimaan daerah termasuk denda keterlambatan pekerjaan belum dipungut atau diterima, (iii) non finansial sebesar $33 \%$ yaitu bukti pertanggungjawaban tidak lengkap atau tidak valid. Tahun 2016 terdapat ketidakpatuhan antara lain: (i) permasalahan yang menyebabkan kerugian daerah sebesar $60 \%$ yaitu belanja tidak sesuai atau melebihi ketentuan (ii) non finansial sebesar $40 \%$ yaitu bukti pertanggungjawaban tidak lengkap atau tidak valid.

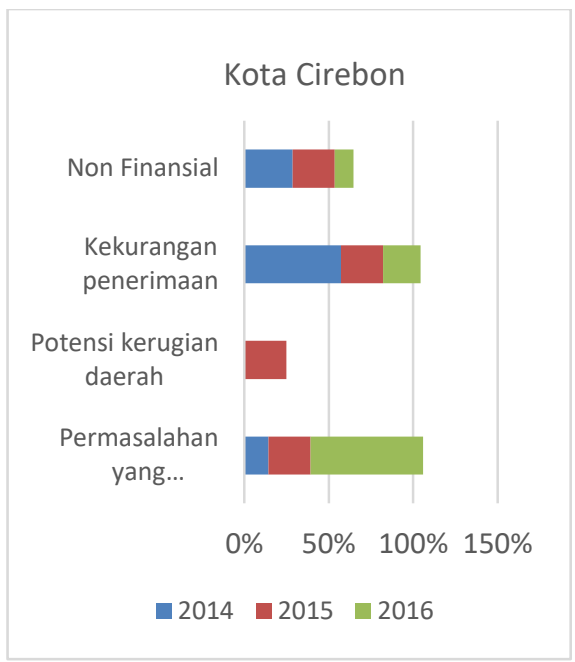

Sumber: Data diolah. 2017

\section{Gambar 2 \\ Rekapitulasi Pemeriksaan atas Ketidakpatuhan Terhadap Peraturan Perundang-Undangan Pada Pemda Kota Cirebon TA 2014, TA 2015 dan TA 2016}

Pada Tahun 2014 terdapat ketidakpatuhan di Kota Cirebon antara lain: (i) permasalahan yang menyebabkan kerugian daerah sebesar $14 \%$ yaitu kelebihan pembayaran selain kekurangan volume pekerjaan dan atau barang (ii) kekurangan penerimaan sebesar $57 \%$ yaitu penerimaan daerah termasuk denda keterlambatan pekerjaan belum dipungut atau diterima, (iii) non finansial sebesar $29 \%$ yaitu penyimpangan peraturan bidang tertentu. Tahun 2015 terdapat ketidakpatuhan, seperti: (i) permasalahan yang menyebabkan kerugian daerah sebesar $25 \%$ yaitu belanja tidak sesuai atau melebihi ketentuan (ii) potensi kerugian daerah sebesar $25 \%$ yaitu kelebihan pembayaran pekerjaan namun belum dilakukan pelunasan pada (iii) kekurangan penerimaan sebesar $25 \%$ yaitu penggunaan langsung penerimaan daerah (iii) non finansial sebesar $25 \%$ yaitu penyetoran penerimaan daerah terlambat. Tahun 2016 terdapat ketidakpatuhan antara lain: (i) permasalahan yang menyebabkan kerugian 
daerah sebesar $67 \%$ yaitu kekurangan volume pekerjaan dan atau barang, belanja tidak sesuai atau melebihi ketentuan dan kelebihan pembayaran selain kekurangan volume pekerjaan dan atau barang serta lain-lain yang mengakibatkan kerugian daerah (ii) kekurangan penerimaan sebesar $22 \%$ yaitu penerimaan daerah termasuk denda keterlambatan pekerjaan belum dipungut atau diterima, (iii) non finansial sebesar $11 \%$ yaitu proses pengadaan barang atau jasa tidak sesuai dengan ketentuan.

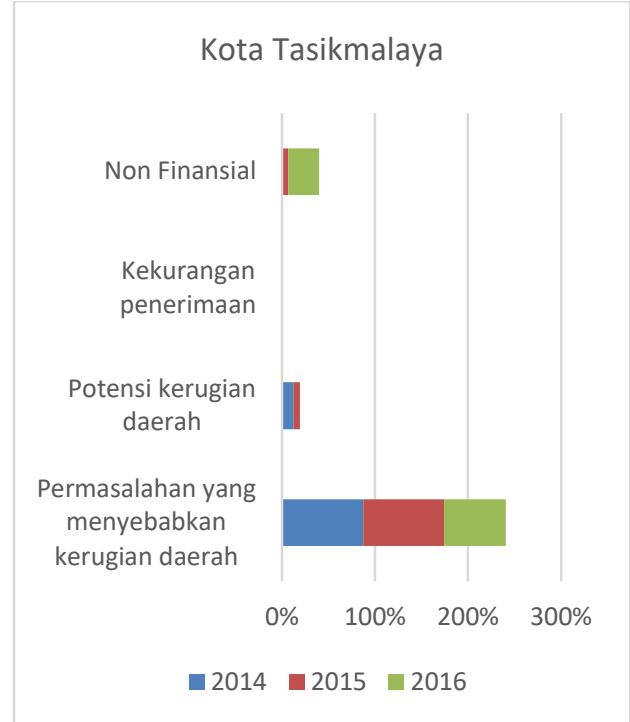

Sumber: Data diolah. 2017

\section{Gambar 3 \\ Rekapitulasi Pemeriksaan atas \\ Ketidakpatuhan Terhadap Peraturan Perundang-Undangan Pada Pemda Kota Tasikmalaya TA 2014, TA 2015 dan TA 2016}

Ketidakpatuhan TA 2014 yang terjadi pada Kota Tasikmalaya, diantaranya: (i) permasalahan yang menyebabkan kerugian daerah sebesar $88 \%$ yaitu belanja tidak sesuai atau melebihi ketentuan dan kelebihan pembayaran selain kekurangan volume pekerjaan dan atau barang (ii) potensi kerugian daerah sebesar $12 \%$ yaitu kelebihan pembayaran pekerjaan namun belum dilakukan pelunasan pembayaran kepada rekanan. Pada TA 2015, diantaranya: (i) permasalahan yang menyebabkan kerugian daerah sebesar $86 \%$ yaitu kekurangan volume pekerjaan dan atau barang, belanja tidak sesuai atau melebihi ketentuan dan kelebihan pembayaran selain kekurangan volume pekerjaan dan atau barang (ii) potensi kerugian daerah sebesar 7\% yaitu kesalahan perhitungan analisa harga satuan pekerjaan (iii) non finansial senilai $7 \%$ yaitu proses pengadaan barang atau jasa tidak sesuai ketentuan. TA 2016 sebagai berikut: (i) permasalahan yang menyebabkan kerugian daerah sebesar $67 \%$ yaitu kekurangan volume pekerjaan dan atau barang dan belanja tidak sesuai atau melebihi ketentuan, (ii) non finansial senilai 33\% yaitu bukti pertanggungjawaban tidak lengkap atau tidak valid.

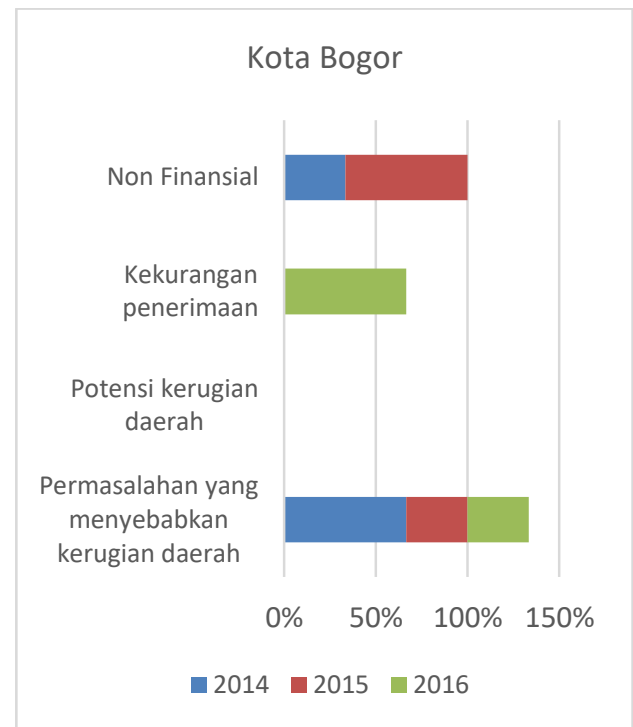

Sumber: Data diolah. 2017

Gambar 4

Rekapitulasi Pemeriksaan atas Ketidakpatuhan Terhadap Peraturan Perundang-Undangan Pada Pemda Kota Bogor TA 2014, TA 2015 dan TA 2016 
Pada TA 2014 Kota Bogor ditemukan ketidakpatuhan dan kecurangan antara lain: permasalahan yang menyebabkan kerugian daerah sebesar $67 \%$ yaitu belanja tidak sesuai atau melebihi ketentuan dan kelebihan pembayaran selain kekurangan volume pekerjaan dan atau barang (ii) non finansial senilai $33 \%$ yaitu bukti pertanggungjawaban tidak lengkap atau tidak valid dan penyimpangan peraturan bidang tertentu. Ketidakpatuhan TA 2015 antara lain: (i) permasalahan yang menyebabkan kerugian daerah sebesar 33\% yaitu belanja tidak sesuai atau melebihi ketentuan dan kelebihan pembayaran selain kekurangan volume pekerjaan dan atau barang (ii) non finansial senilai $67 \%$ yaitu penyimpangan peraturan bidang tertentu, penyetoran penerimaan daerah terlambat, dan lain-lain permasalahan penyimpangan administrasi. Ketidakpatuhan TA 2016 sebagai berikut: (i) permasalahan yang menyebabkan kerugian daerah sebesar 33\% yaitu belanja tidak sesuai atau melebihi ketentuan, (ii) kekurangan penerimaan sebesar $67 \%$ yaitu penerimaan daerah termasuk denda keterlambatan pekerjaan belum dipungut atau diterima dan lain-lain kekurangan penerimaan

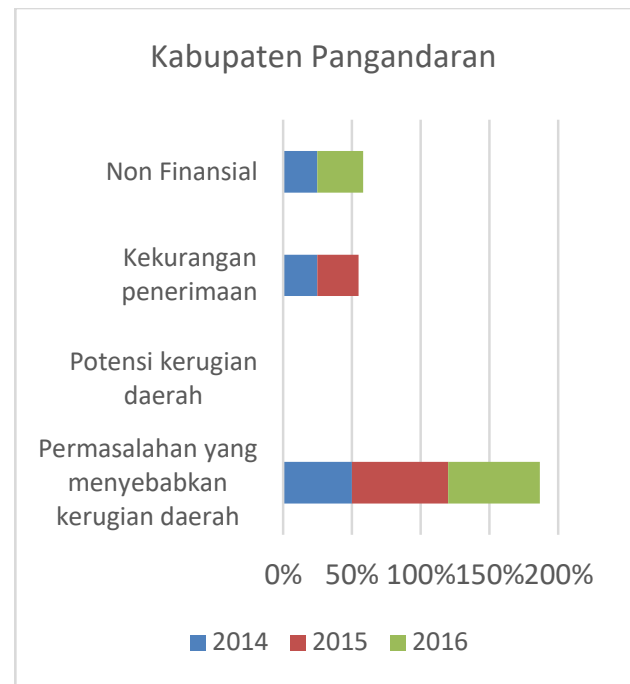

Sumber: Data diolah. 2017

\section{Gambar 5}

Rekapitulasi Pemeriksaan atas

Ketidakpatuhan Terhadap Peraturan

Perundang-Undangan Pada Pemda

Kabupaten Pangandaran TA 2014, TA

2015 dan TA 2016

Ketidakpatuhan TA $2014 \quad$ Kota Pangandaran seperti: (i) permasalahan yang menyebabkan kerugian daerah sebesar 50\% yaitu belanja tidak sesuai atau melebihi ketentuan, kelebihan pembayaran selain kekurangan volume pekerjaan dan atau barang, (ii) kekurangan penerimaan sebesar $25 \%$ yaitu penerimaan daerah termasuk denda keterlambatan pekerjaan belum dipungut atau diterima, (iii) non finansial sebesar $25 \%$ yaitu bukti pertanggungjawaban tidak lengkap atau valid. TA 2015 antara lain: (i) permasalahan yang menyebabkan kerugian daerah sebesar $70 \%$ yaitu kekurangan volume pekerjaan dan atau barang, (ii) kekurangan penerimaan sebesar $30 \%$ yaitu penerimaan daerah termasuk denda keterlambatan pekerjaan belum dipungut atau diterima dan penggunaan langsung penerimaan daerah. TA 2016 seperti: Kota Pangandaran telah ditemukan ketidakpatuhan dan kecurangan seperti: (i) permasalahan yang 
menyebabkan kerugian daerah sebesar $67 \%$ yaitu kekurangan volume pekerjaan dan atau barang dan belanja tidak sesuai atau melebihi ketentuan, (ii) non finansial sebesar $33 \%$ yaitu bukti pertanggungjawaban tidak lengkap atau tidak valid, penyimpangan peraturan bidang tertentu, dan proses pengadaan barang atau jasa tidak sesuai dengan ketentuan.

Sehubungan dengan temuan-temuan pada TA 2016, BPK telah memberikan rekomendasi kepada kepala daerah secara umum, antara lain:

(i) Kerugian

- Memberikan sanksi sesuai ketentuan yang berlaku kepada pejabat atau pegawai yang belum optimal dalam melaksanakan tugas dan tanggungjawab.

- Memerintahkan PPK dan pelaksana atau pengawas lapangan lebih cermat dalam melaksanakan tugas dan tanggungjawabnya dalam pelaksanaan kegiatan swakelola.

- Memerintahkan pejabat atau pegawai yang bertanggungjawab untuk meningkatkan pengawasan dan pengendalian.

- Memerintahkan KPA dan PPK lebih optimal dalam memproses pengembalian sisa uang muka atau pencairan jaminan uang muka.

- Memerintahkan pejabat atau pegawai dan pihak lain yang bertanggungjawab untuk mempertanggungjawabkan

kerugian daerah dengan menyetor ke kas daerah.

(ii) Potensi kerugian daerah

- Melakukan pembatalan dengan kesepakatan antara rekanan dengan dinas terkait serta meminta pengembalian uang muka kepada rekanan.

- Kepala Dinas memerintahkan kepada PPK terkait untuk mempertanggungjawabkan

kelebihan pembayaran dengan melakukan pemotongan atas pembayaran nilai sisa kontrak yang belum dibayarkan.

- Memerintahkan PPTK lebih optimal dalam mengendalikan pelaksanaan kontrak dan memerintahkan rekanan untuk memperbaiki kerusakan pekerjaan.

- Memberikan sanksi sesuai dengan ketentuan peraturan perundangundangan yang berlaku kepada kepala dinas yang tidak optimal dalam mengendalikan dan mengawasi pelaksanaan pekerjaan atau kontrak.

- Melakukan pengawasan dan pengendalian atas pengelolaan aset tetap secara optimal, serta mengkoordinasikan penelusuran keberadaan aset tetap dan upaya pengamanan administrasi dan hukum atas aset tetap terkait.

- Menetapkan status atas aset yang dikuasai oleh pihak lain.

(iii) Kekurangan penerimaan

- Menginstruksikan KPA untuk menyelesaikan proses pencairan klaim atas jaminan pelaksanaan serta jaminan uang muka.

- Memerintahkan kepada pejabat yang bertanggungjawab agar lebih cermat dalam melaksanakan pengawasan dan pengendalian atas kegiatan yang menjadi tanggungjawabnya.

- Menyetorkan sisa dana pada rekening yang sudah tidak digunakan lagi, seperti penampungan dana BOS

- Memproses denda keterlambatan dan kekurangan penerimaan lainnya sesuai dengan ketentuan yang berlaku dan menyetorkannya ke kas daerah.

- Memberikan sanksi sesuai dengan ketentuan yang berlaku kepada pejabat yang lalai dan belum optimal dalam melaksanakan tugas. 
(iv) Penyimpangan administrasi

\section{Kendala Pemerintah Daerah Dalam Memperoleh Opini WTP}

a. Pemeriksaan laporan keuangan

Berdasarkan LHP TA 2014, TA 2015, dan TA 2016 terdapat 3 Kota/Kabupaten yang belum berhasil mendapatkan opini WTP, yaitu: Kabupaten Subang, Kota Bandung, dan Kabupaten Bandung Barat. Berikut rekapitulasi temuan BPK pada Kabupaten Subang TA 2014, TA 2015, dan TA 2016:

\section{Tabel 13}

Rekapitulasi Temuan BPK

Pada Kabupaten Subang TA 2014, TA 2015, dan TA 2016

\begin{tabular}{|c|c|}
\hline TA 2014 & $\begin{array}{l}\text { - Investasi non permanen } \\
\text { lainnya-dana bergulir } \\
\text { - Investasi permanen- } \\
\text { penyertaan modal } \\
\text { pemda } \\
\text { - Aset tetap } \\
\text { - Aset lain-lain } \\
\text { - Anggaran dan realisasi } \\
\text { lain-lain PAD yang sah } \\
\text { - Belanja pegawai, } \\
\text { belanja barang dan }\end{array}$ \\
\hline TA 2015 & Beban dan ekuitas \\
\hline TA 2016 & $\begin{array}{l}\text { - Kas di bendahara dana } \\
\text { BOS } \\
\text { - Nilai aset tetap } \\
\text { - Nilai pendapatan hibah- } \\
\text { dana BOS } \\
\text { - Beban jasa atas } \\
\text { penggunaan dana BOS }\end{array}$ \\
\hline
\end{tabular}

Sumber : Laporan Hasil Pemeriksaan BPK Perwakilan Provinsi Jawa Barat.2017

Kabupaten Subang masih mendapatkan opini WDP karena dari TA 2014 hingga TA 2016 belum dapat mengatasi kendala yang terjadi, seperti: (i) masih terbatasnya sumberdaya manusia yang handal sebagai aparatur Pembina bidang tertentu, serta masih kurang profesional; terutama dalam menangani kegiatan spesifik yang memerlukan keahlian tertentu, (ii) belum memadainya sarana dan prasarana pendukung termasuk salah satunya infrastruktur administrasi yang digunakan untuk menyusun laporan sesuai dengan peraturan perundangan yang berlaku.

Tabel 14

Rekapitulasi Temuan BPK

Pada Kota Bandung TA 2014, TA 2015, dan TA 2016

\begin{tabular}{|c|c|}
\hline TA 2014 & $\begin{array}{l}\text { Piutang pajak } \\
\text { - Piutang sewa tanah } \\
\text { dan bangunan } \\
\text { - Aset tetap tanah, } \\
\text { bangunan, gedung, } \\
\text { peralatan, mesin } \\
\end{array}$ \\
\hline TA 2015 & $\begin{array}{l}\text { - Piutang pajak } \\
\text { - Piutang sewa tanah } \\
\text { dan } \\
\text { - Aset tetap } \\
\text { - Persediaan }\end{array}$ \\
\hline TA 2016 & $\begin{array}{l}\text { - Piutang pajak } \\
\text { - Piutang sewa tanah } \\
\text { - Aset tetap } \\
\text { - Persediaan } \\
\text { - Utang jangka pendek } \\
\text { - Beban barang dan jasa }\end{array}$ \\
\hline
\end{tabular}

Sumber : Laporan Hasil Pemeriksaan BPK

Kota Bandung masih mendapatkan opini WDP karena beberapa temuan dari BPK yang berdampak material. Temuan tersebut hingga TA 2016 belum dapat diatasi karena terkendala hal berikut: (i) penyewa lahan pemerintah dan penunggak pajak belum menuntaskan kewajibannya, (ii) aset tetap yang tidak diketahui keberadaannya, (iii) penilaian aset tidak sesuai dengan standar akuntansi, (iv) sertifikat tanah dalam proses pengadilan. 
Tabel 15

Rekapitulasi Temuan BPK

Pada Kabupaten Bandung Barat TA 2014, TA 2015, dan TA 2016

\begin{tabular}{|c|c|}
\hline TA 2014 & - Aset tetap \\
\hline TA 2015 & - Aset tetap \\
\hline TA 2016 & $\begin{array}{ll}\text { - } & \text { Kas lainnya-Kas di } \\
\text { bendahara BOS } \\
\text { - } & \text { Beban barang } \\
\text { - } & \text { Piutang PBB } \\
& \text { pedesaan dan } \\
\text { perkotaan } \\
\text { - } & \text { Aset tetap dan } \\
\text { akumulasi } \\
\text { penyusutan } \\
\end{array}$ \\
\hline
\end{tabular}

Sumber : Laporan Hasil Pemeriksaan BPK

Berdasarkan tabel rekapitulasi temuan BPK atas LKPD Kabupaten Bandung Barat TA 2014, 2015, dan 2016 belum berhasil mengatasi masalah pada laporan keuangan TA 2014, 2015, 2016 sehingga pada TA 2016 masih mendapatkan opini WDP. Kendala yang terjadi pada Kabupaten Bandung Barat, antara lain: (i) sumber daya manusia pengelola pajak dan retribusi daerah masih terbatas, baik jumlah maupun kompetensinya, (ii) aset tetap belum dapat ditelusuri keberadaannya, (iii) penyajian nilai aset tetap tidak sesuai dengan Standar Akuntansi Pemerintah, (iv) tidak tersedia rincian data belanja, (v) tidak dapat menjelaskan selisih penggunaan dana BOS pada laporan operasional dengan perhitungan matematis, (vi) tidak dapat menjelaskan koreksi rincian piutang PBB Pedesaan dan Perkotaan, (vii) tidak ada rincian yang memadai atas koreksi selisih kurang akumulasi penyusutan.

\section{b. Pemeriksaan atas pengendalian} internal

Pemeriksaan atas sistem pengendalian internal dilakukan oleh BPK untuk menentukan prosedur pemeriksaan dalam rangka memberikan opini atas kewajaran laporan keuangan. Kelemahan dalam sistem pengendalian intern dapat dikelompokkan menjadi tiga jenis, yaitu kelemahan sistem pengendalian akuntansi dan pelaporan, kelemahan sistem pengendalian pelaksanaan anggaran pendapatan dan belanja, dan kelemahan struktur pengendalian intern. Berikut rekapitulasi pemeriksaan sistem pengendalian intern atas kelemahan sistem pengendalian akuntansi dan pelaporan, kelemahan sistem pengendalian pelaksanaan anggaran pendapatandan kelemahan strukur pengendalian internal.

Tabel 16

Hasil Pemeriksaan atas Sistem

Pengendalian Intern Pemda Kabupaten Subang TA 2014, TA 2015, dan TA 2016

\begin{tabular}{|l|c|c|c|}
\hline \multicolumn{1}{|c|}{ Tahun } & 2014 & 2015 & 2016 \\
\hline $\begin{array}{l}\text { Kelemahan } \\
\text { struktur } \\
\text { pengendalian } \\
\text { intern }\end{array}$ & - & - & - \\
\hline $\begin{array}{l}\text { Kelemahan } \\
\text { sistem } \\
\text { pengendalian } \\
\text { pelaksanaan } \\
\text { anggaran } \\
\text { pendapatan dan } \\
\text { belanja }\end{array}$ & $\sqrt{ }$ & - & $\sqrt{ }$ \\
\hline $\begin{array}{l}\text { Kelemahan } \\
\text { sistem } \\
\text { pengendalian } \\
\text { akuntansi dan } \\
\text { pelaporan }\end{array}$ & $\sqrt{ }$ & $\sqrt{ }$ & $\sqrt{ }$ \\
\hline
\end{tabular}

Sumber: LHP BPK Perwakilan Provinsi Jabar 2017

Pada TA 2014 hingga 2016 tidak terdapat kelemahan pada struktur pengendalian internal. Namun TA 2014 terdapat kelemahan sistem pengendalian pelaksanaan anggaran pendapatan dan belanja sebesar $13 \%$ disebabkan oleh penyimpangan terhadap peraturan tentang $33 \%$. Kelemahan pada sistem pengendalian akuntansi dan pelaporan pada TA 2014 sebesar $88 \%$ disebabkan oleh pencatatan belum dilakukan dan proses penyusunan laporan tidak sesuai ketentuan. Kelemahan 
ini masih terjadi pada TA 2015 sebesar 100\%, dan pada TA 2016 sebesar 67\%.

\section{Tabel 17}

Hasil Pemeriksaan atas Sistem Pengendalian Intern Pemda Kota Bandung TA 2014, TA 2015, dan TA 2016

\begin{tabular}{|l|c|c|c|}
\hline \multicolumn{1}{|c|}{ Tahun } & 2014 & 2015 & 2016 \\
\hline $\begin{array}{l}\text { Kelemahan } \\
\text { struktur } \\
\text { pengendalian } \\
\text { intern }\end{array}$ & - & - & - \\
\hline $\begin{array}{l}\text { Kelemahan } \\
\text { sistem } \\
\text { pengendalian } \\
\text { pelaksanaan } \\
\text { anggaran } \\
\text { pendapatan dan } \\
\text { belanja }\end{array}$ & - & $\sqrt{ }$ & $\sqrt{ }$ \\
\hline $\begin{array}{l}\text { Kelemahan } \\
\text { sistem } \\
\text { pengendalian } \\
\text { akuntansi dan } \\
\text { pelaporan }\end{array}$ & $\sqrt{ }$ & $\sqrt{ }$ & $\sqrt{ }$ \\
\hline
\end{tabular}

Sumber: LHP BPK Perwakilan Provinsi Jabar 2017

Pada TA 2014 hingga TA 2016 tidak terjadi kelemahan struktur pengendalian intern. Pada TA 2014 tidak terjadi kelemahan sistem pengendalian pelaksanaan anggaran pendapatan dan belanja namun pada TA 2015 ditemukan adanya kelemahan sebesar $20 \%$ disebabkan oleh pengelolaan dana BOS yang belum memadai dan masih terjadi sebesar 17\% pada TA 2016. Kelemahan sistem pengendalian akuntansi dan pelaporan terjadi pada TA 2014 sebesar 100\% disebabkan oleh pencatatan belum dilakukan masih terjadi pda TA 2015 sebesar $80 \%$ dan TA 2016 sebesar $83 \%$.
Tabel 18

Hasil Pemeriksaan atas Sistem

Pengendalian Intern Pemda Kabupaten Bandung Barat TA 2014, TA 2015, dan TA 2016

\begin{tabular}{|l|c|c|c|}
\hline \multicolumn{1}{|c|}{ Tahun } & 2014 & 2015 & 2016 \\
\hline $\begin{array}{l}\text { Kelemahan } \\
\text { struktur } \\
\text { pengendalian } \\
\text { intern }\end{array}$ & - & $\sqrt{ }$ & - \\
\hline $\begin{array}{l}\text { Kelemahan } \\
\text { sistem } \\
\text { pengendalian } \\
\text { pelaksanaan } \\
\text { anggaran } \\
\text { pendapatan dan } \\
\text { belanja }\end{array}$ & $\sqrt{ }$ & $\sqrt{ }$ & $\sqrt{ }$ \\
\hline $\begin{array}{l}\text { Kelemahan } \\
\text { sistem } \\
\text { pengendalian } \\
\text { akuntansi dan } \\
\text { pelaporan }\end{array}$ & $\sqrt{ }$ & $\sqrt{ }$ & \\
\hline
\end{tabular}

Sumber: LHP BPK Perwakilan Provinsi Jabar 2017

Pada TA 2014 dan 2016 tidak terdapat kelemahan pada struktur pengendalian internal. namun TA 2015 terdapat kelemahan sebesar 18\% disebabkan oleh SOP yang tidak ditaati. Kelemahan sistem pengendalian pelaksanaan anggaran pendapatan dan belanja pada TA 2014 terjadi sebesar 29\% dikarenakan pelaksanaan kebijakan menyebabkan hilangnya potensi penerimaan, TA 2015 $27 \%$ dikarenakan selain pelaksanaan kebijakan yang menyebabkan hilangnya penerimaan tetapi juga perencanaan kegiatan yang tidak memadai, hal ini masih terjadi pada TA sebesar $201625 \%$. Kelemahan sistem pengendalian akuntansi dan pelaporan pada TA 2014 terjadi sebesar $71 \%$ dikarenakan pencatatan belum dilakukan dan proses penyusunan laporan tidak sesuai ketentuan, hal ini masih terjadi pada TA 2015 sebesar 55\%, sedangkan pada TA sebesar $75 \%$ disebabkan oleh pencatatan belum dilakukan atau tidak akurat. 


\section{d. Pemeriksaan atas kepatuhan terhadap peraturan perundang- undangan}

Permasalahan ketidakpatuhan terhadap peraturan perundang-undangan meliputi permasalahan ketidakpatuhan yang berdampak finansial terdiri dari permasalahan yang menyebabkan kerugian daerah, potensi kerugian daerah, dan kekurangan penerimaan. Selain itu, terdapat permasalahan ketidakpatuhan yang tidak berdampak finansial berupa penyimpangan administrasi.

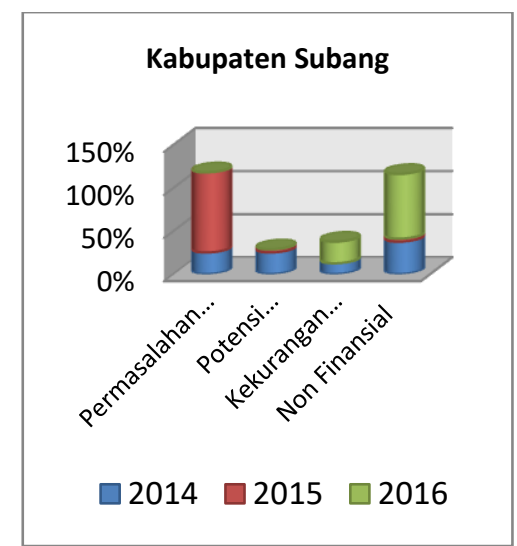

Sumber: Data diolah. 2017

\section{Gambar 6 \\ Rekapitulasi Pemeriksaan atas \\ Ketidakpatuhan Terhadap Peraturan \\ Perundang-Undangan Pada Pemda \\ Kabupaten Subang TA 2014, TA 2015 \\ dan TA 2016}

Pada TA 2014 terdapat permasalahan yang menyebabkan kerugian daerah sebesar 25\% disebabkan belanja yang tidak sesuai atau melebihi ketentuan, pada TA 2015 sebesar 93\% dikarenakan kelebihan pembayaran, TA 2016 sudah dapat diatasi, sehingga tidak terjadi lagi kelemahan. Pada TA 2014 terdapat potensi kerugian daerah 25\%, TA 2015 sebesar 4\% disebabkan oleh aset yang dikuasai pihak lain, dan TA 2016 tidak terjadi lagi kelemahan ini. Terdapat temuan kekurangan penerimaan pada TA 2014 13\% disebabkan oleh penggunaan langsung penerimaan daerah. Pada TA 2016 sebesar $25 \%$ dikarenakan penerimaan Negara atau daerah termasuk denda keterlambatan pengerjaan belum dipungut atau diterima. Pada TA 2014 terdapat temuan non finansial sebesar 38\% disebabkan oleh bukti pertanggungjawaban tidak lengkap atau valid, penyimpangan peraturan, penyetoran penerimaan negara atau daerah terlambat. Pada TA 2015 sebesar 4\% disebabakan oleh proses pengadaan barang atau jasa tidak sesuai dengan ketentuan, dan TA 2016 sebesar $75 \%$ dikarenakan bukti pertanggungjawaban tidak lengkap, dan adanya penyimpangan peraturan yang berlaku. Permasalah kepatuhan terhadap undang-undang pada tahun 2016 terjadi disebabkan oleh: pengendalian internal dan pengawasan atas pengelolaan keuangan daerah masih rendah, verifikatur kurang cermat dalam melakukan verifikasi bukti pertanggungjawaban belanja, belum dikenakannya sanksi kepada bendahara pengeluaran yang tidak cermat dalam menyetoran ketekoran kas ke kas daerah, belum adanya penagihan denda keterlambatan pekerjaan, dan belum adanya kebijakan strategis terkait penyelesaian pekerjaan.

Pada Kota Bandung terdapat permasalahan, sebagai berikut: 


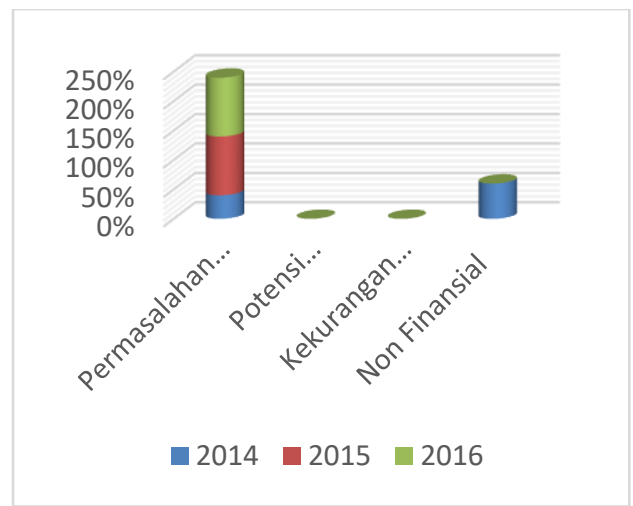

Sumber: Data diolah. 2017

\section{Gambar 7 \\ Rekapitulasi Pemeriksaan atas \\ Ketidakpatuhan Terhadap Peraturan \\ Perundang-Undangan Pada Pemda Kota Bandung TA 2014, TA 2015 dan TA 2016}

Terjadi permasalahan yang menyebabkan kerugian Negara yaitu belanja tidak sesuai dan kelebihan pembayaran pada Tahun 2014 40\%, Tahun 2015 100\%, dan Tahun 2017 sebesar 100\%. Permasalahan tersebut disebabkan oleh: masih lemahnya pengendalian internal dan pengawasan atas belanja modal dan penyetoran kelebihan pembayaran, belum dilakukan pemotongan atas pembayaran sisa nilai kontrak, dan meminta kepada penyedia jasa menyelesaikan sisa pekerjaan

Sedangkan permasalahan yang terjadi pada Kabupaten Bandung Barat antara lain:

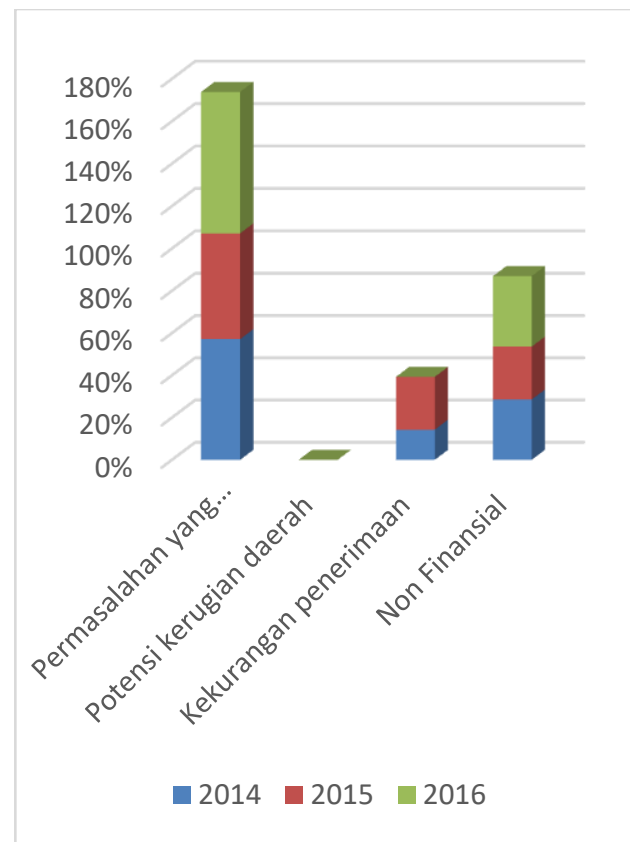

Sumber: Data diolah. 2017

\section{Gambar 8}

Rekapitulasi Pemeriksaan atas

Ketidakpatuhan Terhadap Peraturan

Perundang-Undangan Pada Pemda

Kabupaten Bandung Barat TA 2014, TA

2015 dan TA 2016

Pada tahun 2014 terjadi kekurangan volume pekerjaan, belanja tidak sesuai ketentuan, dan kelebihan pembayaran sebesar 57\%, penerimaan Negara dan denda keterlambatan yang belum diterima sebesar $14 \%$, bukti pertanggungjawaban tidak valid sebesar 29\%. Pada tahun 2015 terjadi kekurangan volume perkerjaan dan biaya perjalanan dinas ganda sebesar 50\%, penerimaan Negara dan denda keterlambatan belum dipungut sebesar 25\%, bukti pertanggungjawaban tidak valid, penyimpangan peraturan, dan penyetoran Negara yang terlambat sebesar $25 \%$. Pada tahun 2017 terjadi belanja melebihi ketentuan dan kelebihan pembayaran sebesar $67 \%$, serta bukti pertanggungjawaban tidak valid $33 \%$. 
Permasalahan tersebut disebabkan oleh belum cermatnya verifikasi bukti pertanggungjawaban belanja kegiatan, kurangnya pengendalian dan pengawasan pengelolaan belanja, dan belum lengkapnya bukti pertanggungjawaban belanja.

\section{Simpulan dan Saran}

Sebagai bentuk pertanggungjawaban atas pengelolaan keuangan atas dana yang bersumber dari APBN, setiap pemerintah daerah kabupaten atau kota diwajibkan untuk menyusun LKPD sesuai dengan Standar Akuntansi Pemerintahan. Hal ini juga merupakan perwujudan prinsip transparansi dalam pengelolaan keuangan daerah. Untuk menilai kewajaran penyajian LKPD, BPK berdasarkan Undang-Undang Nomor 15 Tahun 2006 diberikan wewenang memeriksa pengelolaan dan tanggung jawab keuangan negara. Pemeriksaan yang dilakukan oleh BPK meliputi: pemeriksaan atas laporan keuangan, pemeriksaan atas sistem pengendalian intern, dan pemeriksaan atas kepatuhan peraturan perundang-undangan. Pada akhir pemeriksaan, BPK menerbitkan Laporan Hasil Pemeriksaan (LHP) yang didalamnya terdiri dari opini auditor BPK, temuan, rekomendasi dan laporan keuangan LKPD yang telah diaudit. Opini yang diberikan oleh BPK dapat berupa: wajar tanpa pengecualian (WTP), wajar dengan pengecualian (WDP), tidak memberikan pendapat (TMP), dan tidak wajar (TW).

Provinsi Jawa Barat terdiri dari 26 kabupaten dan kota. Dalam 3 tahun terakhir (2014 - 2016) sebagian besar pemerintah kota (Pemkot) dan pemerintah kabupaten (Pemkab) telah memperoleh opini WTP. 5 Pemkab/Pemkot pada tahun 2014 dan 2015 masih memperoleh opini WDP, yaitu: Kabupaten Bandung, Kota Cirebon, Kota Tasikmalaya, Kota Bogor, dan Kabupaten Pangandaran. Opini WTP atas 5 Pemkab/Pemkot tersebut baru diperoleh pada tahun 2016. Namun sampai dengan tahun 2016, terdapat 3 Pemkot/Pemkab yang masih memperoleh opini WDP, yaitu: Kabupaten Subang, Kota Bandung, dan Kabupaten Bandung Barat.

Keberhasilan 5 Pemkab/Pemkot dalam memperoleh opini WTP, disebabkan karena Pemkab/Pemkot telah menyusun LKPD dengan SAP berbasis akrual. Salah satu faktor pendukung lainnya dikarenakan Pemkot/Pemkab telah menindaklanjuti rekomendasi dari BPK atas LKPD tahun sebelumnya, memperbaiki kelemahan pada sistem pengendalian intern, dan meningkatkan kepatuhan terhadap undangundang. Perubahan opini juga didukung oleh aspek sumber daya manusia, seperti: komitmen dan integritas kepala daerah dan perangkatnya serta kompetensi SDM khususnya di bidang akuntansi. Selain itu, perbaikan yang ada perlu didukung sistem informasi yang memadai. Predikat WTP yang diperoleh Pemkot/Pemkab bukan berarti penyelenggaraan pemerintah berjalan tanpa masalah. Melainkan masalah yang terjadi masih berada dalam ambang toleransi yang terus ditindaklanjuti untuk diperbaiki.

Di sisi lain, ketiga Pemkot/Pemkab yang belum memperoleh opini WTP disebabkan oleh beberapa kendala, yang mayoritas berupa salah saji dalam akun asset tetap dan asset lancar. Untuk akun asset tetap, permasalahan yang umumnya terjadi adalah penyajian asset tetap yang tidak berdasarkan nilai perolehan atau nilai wajar, tidak diketahui keberadaannya, tidak disajikan, selisih antara realisasi belanja modal berdasarkan LRA dengan perhitungan mutasi bidang aset yang tidak dapat dijelaskan, selisih antara saldo aset tetap dengan rincian aset tetap pada aplikasi Atisibada yang tidak dapat dijelaskan, koreksi kurang atas akumulasi penyusutan yang tidak didukung rincian yang memadai. Untuk akun aset lancar, mayoritas masalah ialah saldo minus kas di bendahara BOS yang tidak dijelaskan dan terdapat selisih saldo di bendahara BOS dengan 
rekapitulasi laporan dari sekolah. Piutang PBB P2 terdapat selisih antara piutang yang dsajikan dengan Daftar Himpunan Ketetapan Pajak, piutang pajak tidak diakui oleh wajib pajak, tidak dapat ditelusuri, dan tidak disajikan. Saldo persediaan masih ada yang tidak disajikan berdasarkan hasil perhitungan fisik akhir tahun. Selain aspek laporan keuangan, kendala yang ada juga disebabkan karena masih banyak kelemahan pada sistem pengendalian intern serta ketidakpatuhan dan kecurangan terhadap Peraturan Perundang-Undangan.

Sehubungan dengan belum diperolehnya opini WTP oleh Kabupaten Subang, Kota Bandung, dan Kabupaten Bandung Barat, Pemkot/Pemkab diharapkan dapat segera menyusun strategi untuk menindaklanjuti rekomendasi dari BKP. Diharapkan pula Pemkot/Pemkab dapat segera mengatasi kelemahan pada sistem pengendalian intern serta meningkatkan kepatuhan terhadap Peraturan Perundang-undangan. Disamping itu, Pemda dan Pemkot diharapkan dapat meningkatkan kompetensi SDM khususnya di bidang Akuntansi melalui pelatihan terkait akuntansi pemerintahan, penyusunan laporan keuangan, pelatihan teknis penggunaan aplikasi sistem informasi, serta bekerjasama dengan BPKP untuk konsultasi penyusunan laporan keuangan. Selain itu, yang tidak kalah penting adalah komitmen dan integritas kepala daerah dan perangkatnya dalam pengelolaan dan pemberdayaan keuangan daerah.

\section{Daftar Pustaka}

Undang-Undang No.17 Tahun 2003 tentang Keuangan Negara

Undang-Undang No.1 Tahun 2004 tentang Perbendaharaan Negara

Undang-Undang No.15 Tahun 2004 tentang Pemeriksaan Pengelolaan dan Tanggungjawab Keuangan Negara
Undang-Undang No 32 Tahun 2004 tentang Pemerintahan Daerah

Undang-Undang No.15 Tahun 2006 tentang Badan Pemeriksa Keuangan

Peraturan Pemerintah No.58 Tahun 2005 tentang Pengelolaan Keuangan Daerah

Peraturan Menteri Dalam Negeri No.21 Tahun 2011 tentang Pedoman Pengelolaan Keuangan Daerah

Peraturan Menteri Dalam Negeri No.13 Tahun 2006 jo Peraturan Menteri Dalam Negeri No.21 Tahun 2011 tentang Pedoman Pengelolaan Keuangan Daerah

Kementrian Keuangan. 2017. Laporan Keuangan Pemerintah Pusat. https://www.kemenkeu.go.id/Publik asi/laporan-keuangan-pemerintahpusat-2016. Diakses pada (tanggal 10 Juli 2017)

Direktorat Jenderal Perimbangan Keuangan. 2016. Dana Alokasi Umum.

http://www.djpk.depkeu.go.id/wpcontent/uploads/2016/01/DAU.pdf. Diakses pada (tanggal 11 Juli 2017)

Peraturan Badan Pemeriksa Keuangan Tahun 2017 tentang Standar Pemeriksaan Keuangan Negara. Badan Pemeriksa Keuangan Republik Indonesia

Badan Pemeriksa Keuangan. 2016. Mengenal Lebih Dekat BPK-Sebuah Panduan Populer.

Badan Pemeriksa Keuangan Republik Indonesia. 2017. Ikhtisar Hasil Pemeriksaan Semester I tahun 2016.http://www.bpk.go.id/assets/fil es/ihps/2016/I/ihps_i_2016_1475566 035 pdf. Diakses pada (tanggal 10 Juli 2017)

Badan Pemeriksa Keuangan Republik Indonesia. 2017. Ikhtisar Hasil Pemeriksaan Semester I tahun 2016. http://www.bpk.go.id/assets/files/ihp s/2016/II/ihps_ii_2016_1491461165. pdf. Diakses pada (tanggal 10 Juli 2017) 
Badan Pemeriksa Keuangan Republik Indonesia. 1 November 2017. Tak Kunjung WTP Kota Bandung Masih Terganjal Masalah Aset. http://bandung.bpk.go.id/?p=10915.

Diakses pada (tanggal 4 Januari 2018)

Badan Pusat Statistik. 2017. Statistik Keuangan atau Kota 2015-2016 Sumatera Jawa. Pengaruh Skeptisme Profesional, Etika, Pengalaman, Dan Keahlian Audit Terhadap Ketepatan Pemberian Opini Oleh Auditor Diakses pada (tanggal 10 Juli 2017)

Bastian, Indra. 2014. Audit Sektor Publik. Jakarta: Salemba Empat

Budiartha, Ketut. 2007. "Menelusuri Opini Auditor Independen atas LKPD Pemerintah Provinsi Bali”. Jurnal Ilmiah Akuntansi dan Bisnis. Universitas Udayana

Haryadi, Anda Dwi. 2010. "Pengaruh Reviu Inspektorat dan Nilai Temuan Pemeriksaan Terhadap Opini Audit BPK". Jurnal Akuntansi dan Manajemen, Vol.5 No. 2. Politeknik Negeri Padang

Halim dan Kusufi. 2014. Teori, Konsep, dan Aplikasi Akuntansi Sektor Publik. Jakarta: Salemba Empat

Kantor Berita RMOL JABAR Rakyat Merdeka Online Grup. 31 Maret 2017. Kejar WTP, Pemkab Bandung Barat Tertibkan Dokumentasi Aset. http://www.rmoljabar.com/read/201 7/03/31/39283/Kejar-WTP,-

Pemkab-Bandung-Barat-TertibkanDokumentasi-Aset-. Diakses pada (tanggal 4 Januari 2018)

Kantor Berita RMOL JABAR Rakyat Merdeka Online Grup. 28 Agustus 2017. Ingin WTP, Pemkab Bandung Barat Datangi Kabupaten Bandung. http://www.rmoljabar.com/read/201 7/08/28/52618/Ingin-WTP,-PemkabBandung-Barat-datangi-KabupatenBandung-. Diakses pada (tanggal 4 Januari 2018)
Maabuat, Justisia Sulastri, Jenny Morasa, dan David P.E. Saerang. 2016. "Pengaruh Kelemahan Sistem Pengendalian Internal, Ketidakpatuhan Pada Peraturan Perundang-undangan dan Penyelesaian Kerugian Negara Terhadap Opini BPK-RI atas Laporan Keuangan Pemerintah Daerah di Indonesia". Accountability, Vol.5, No. 2. Universitas sam Ratulangi

Sari, Adelia Pramita, Dwi Martani dan Dyah Setyaningrum. 2015. "Pengaruh Temuan Audit, Tindak Lanjut Hasil Pemeriksaan dan Kualitas Sumber Daya Manusia terhadap Opini Audit melalui Tingkat Pengungkapan Laporan Keuangan Kementerian atau Lembaga". Simposium Nasional Akuntansi XVIII. Medan

Seputar BandungRaya. 12 Juni 2017. Empat Faktor LKPD Kota Bandung Menuju Opini WTP. http://www.seputarbandungraya.com /2017/06/empat-faktor-lkpd-kotabandung-menuju.html. Diakses pada (tanggal 4 Januari 2018)

Siregar, Silky Raditya. 2012. "FaktorFaktor yang Mempengaruhi Pertimbangan Opini Auditor atas Laporan Keuangan Pemerintah Daerah Istimewa Yogyakarta”. Accounting Analysis Journal, Vol. 1, No. 2. Universitas Negeri Semarang Sugiyono. 2008. Metode Penelitian Bisnis. Bandung: Alfabeta

Susanto, Herry. 2012. Membangun Kesadaran dan Kepedulian Sukarela Wajib Pajak. http://www.pajak.go.id/content/mem bangun-kesadaran-dan-kepeduliansukarela-wajib-pajak. Diakses pada (tanggal 10 Juli 2017) 
Jurnal Akuntansi a Volume 12 Nomor 1, Mei 2020: 23-46

Wulandari, Indriyani dan Bandi. 2015. "Pengaruh E-Government, Kapabilitas APIP, dan Persentasi Penyelesaian Tindak Lanjut Terhadap Opini Audit Laporan Keuangan Pemerintah Daerah di Indonesia". Jurnal Akuntansi dan Bisnis, Vol. 15, No. 2. Universitas Sebelas Maret. 